\title{
PROBIOTIC BACTERIA AS A TOOL TO PREVENT FUNGAL GROWTH AND AFLATOXINS PRODUCTION BY Aspergillus parasiticus

\author{
AbdAlla, E. A. M. ${ }^{1}$; Y. Saleh ${ }^{2}$; Mary Sobhy ${ }^{2}$; Soheir E. Aly ${ }^{1}$ and \\ Amal S. Hathout ${ }^{1}$ \\ 1- Dept. of Food Toxicology \& Contaminants, National Research Center, \\ Cairo, Egypt \\ 2- Botany Dept., Faculty of Science, Cairo University, Giza, Egypt \\ ABSTRACT
}

Lactobacillus strains are used as probiotic bacteria in fermented dairy products and other fermented food products, whereas they are known to prolong the shelf life of these products. The inhibitory effect of cell free supernatant (CFS) of several Lactobacillus species on mycelium growth and the aflatoxin production by the aflatoxigenic strain of Aspergillus parasiticus was studied. A complete inhibition $(100 \%)$ of mycelium growth and aflatoxin production was recorded when cell free supernatant of Lactobacillus casei was placed in a dialysis sac or in the medium without a dialysis sac or on the insertion of $A$. parasiticus after 16 hours with $L$. casei. Both $L$. reuteri and $L$. gasseri inhibited mycelium growth and aflatoxin production but to a lesser extent.

Cell free supernatant of $L$. acidophilus and $L$. bulgaricus showed the lowest effect on aflatoxin production as well as on mycelium growth. The inoculation of bacterial strains of $L$. casei, $L$. gasseri and $L$. reuteri before fungal growth inoculation by 16 hours caused inhibitory effects on mycelium growth and aflatoxin production. But these indications were not observed for the other treatments of $L$. acidophilus or L. bulgaricus.

The probiotic strains ( $L$. casei, $L$. reuteri) with higher antifungal activity were used and incorporated in the manufacture of Ras cheese to replace the norma starters ( $S$. thermophilus, L. bulgaricus), where they prevented the growth of fungi during the three month of the storage period.

In conclusion probiotic bacteria may be able to produce active substances that can inhibit aflatoxins production by $A$. parasiticus in most treatments used, and the inhibitory effect depends on the type of lactic acid and / or the treatment used.

Keywords: probiotic bacteria, Aspergillus parasiticus, fungal growth and aflatoxin production, Ras cheese.

\section{INTRODUCTION}

Ras cheese is the main Egyptian hard cheese that is rather similar to the Greek, Kefalotyri, whereas the name in both countries means, " head " (Dabiza and Fathi, 2003). Ras cheese is now the best-known hard cheese in Egypt and indeed through out the Arab world (Abou-Donia, 2002). The contamination of dairy products with undesirable moulds such as the genera Aspergillus, Penicillium, Rhizopus, Fusarium and Mucor is a serious and frequently disturbing problem in dairy industry. The potentially toxigenic species within the genera Penicillium, Aspergillus and Fusarium were mainly detected in cheeses (Montagna et al., 2004). Many molds find cheese an excellent medium for growth and they can become moldy during ripening, curing, refrigerated storage and also after the cutting and slicing with unclean equipment in shops or at home (Abu Sree, 1997). Mold growth on cheese is considered undesirable because of their growth imparted musty off-flavors to 
AbdAlla, E. A. M. et al.

the cheese. Certain species of these genera are able to proliferate and produce toxins at low storage temperatures. The presence of aflatoxins in dairy products may be the result of the contamination of milk caused by contamination of feeding stuff consumed by the cow, or direct fungal contamination of dairy products which may result in the formation of aflatoxins (Van Egmond, 1989). Aflatoxin $M_{1}$ was found in $89.47 \%$ of cheese samples collected from supermarkets during August in Bursa, Turkey (Oruc and Sonal, 2001).

Aflatoxins are a group of mycotoxins with mutagenic, carcinogenic and immunosuppressive properties (Eaton and Gallagher, 1994, IARC, 1993). They are produced by toxigenic $A$. flavus and $A$. parasiticus and $A$. nomius strains (Peltonen et al., 2001). Aflatoxins have been found in many food and animal feeds (Wood, 1989) and their production in such commodities can be influenced by several factors, including temperature, water activity, $\mathrm{pH}$, available nutrients and competitive growth of other microorganisms (Ellis et al., 1991). Decontamination of food and feed containing aflatoxins is an objective for improving the food and feed supply. Several techniques are used for the preservation of food and feeds by means of physical methods and several chemical additives (Farkas, 2001 and Davidson, 2001). A variety of physical, chemical and biological approaches have been reported to degrade aflatoxins (Park, 1993 and Piva et al., 1995). The current methods are not very effective and require expensive equipment and may cause losses in the nutritional quality of treated commodities. In addition, the undesirable health effects of such treatments have not been fully evaluated (Phillips et al., 1994).

There is a great demand for novel strategies to prevent both the formation of aflatoxins in food and feed and the impact of aflatoxin contamination. Therefore biological decontamination using microorganisms is one of the well-known strategies for management of aflatoxins in food and feeds. Among the different potential decontaminating microorganisms, lactic acid bacteria represent a unique group, which is widely used in food fermentation and preservation (Shetty and Jespersen, 2006).

Lactic acid bacteria are found in many nutrient rich environment and occur naturally in various food products such as dairy and meat products, and vegetables (Carr et al., 2002). They have traditionally been used as natural bio-preservatives of food and feed to extend shelf life and enhanced safety of foods obtained by using the natural or added microflora and their antimicrobial products (Ross et al., 2002). Lactic acid bacteria play an essential role in the majority of food fermentation, and a wide variety of strains are routinely employed as starter cultures in the manufacture of dairy products. The protective effect of lactic acid bacteria against food mutagens such as heterocyclic amines, $\mathrm{N}$-nitroso compounds and aflatoxins has been reported (Sreekuman and Hosono, 1998 and El-Nezami et al., 2000).

The general public demands a reduced use of chemical preservatives or additives in food and feed and demands a stimulated research on antifungal lactic acid bacteria as bio-preservatives (Brul and Coote, 1999 and Schnurer and Magnusson, 2005). Therefore, the purpose of this investigation is to evaluate the role of some probiotic strains against 
fungal growth and aflatoxin production by $A$. parasiticus on media, and also selecting the probiotic strains with the most antifungal activity to be applied in the manufacture of Ras cheese with antimycotytic properties.

\section{Cultures: -}

\section{MATERIALS AND METHODS}

A- Fungal strain: Aspergillus parasiticus was obtained from Agriculture Research Service, National Center for Agriculture, U. S. A.

B- Bacterial strains: Lactobacillus acidophilus, L. bulgaricus L. casei, L. reuteri and $S$. thermophilus were obtained from Denmark, and L. gasseri LA39 from Dr. T. Saito, Japan.

\section{Media: -}

DeMan Rogosa Sharpe (MRS) broth, Purchased from Fluka Biochemika and Potato Dextrose Agar (PDA) Purchased from DIFCO Laboratory, Detroit, U.S.A.

\section{Aflatoxins standards:}

Aflatoxins $B_{1}, B_{2}$, were purchased from Aldrich chemical Co., P. O. Box 355, Milw, WI 53201, 414-273-3850, U. S. A. while $G_{1} \& G_{2}$ were purchased from Sigma chemical company, P. O. Box 14508, St. Louis, MO 63178, U. S. A.

\section{Preparation of inoculum: -}

A strain of $A$. parasiticus was maintained on potato dextrose agar (PDA) slants for 7 to 10 days at $28^{\circ} \mathrm{C}$, after which the spore suspension was prepared, using saline solution containing $0.05 \%$ Tween 80 and gently dislodging the spores with a flamed wire loop. The spore suspension was then passed through sterile cheesecloth to remove mycelia debris as described by Bullerman et al. (1990).

\section{Preparation of cell free supernatant (CFS):}

Lactic acid bacteria were maintained and stored in sterile litmus milk. For each experiment, the species were transferred to $10-\mathrm{ml}$ sterile modified MRS broth for regeneration by the method described by Bullerman et al. (1990). Cultures were transferred through 4 days by placing $0.1 \mathrm{ml}$ of a 24-h culture to $10 \mathrm{ml}$ of fresh MRS broth. After centrifuging at $445 \times \mathrm{g}$ for 10 minutes, the last 24-h culture was collected. The supernatant was separated from cell pellet and filtered through a $0.45 \mu$ sterile membrane filter to remove remaining cells. The cell pellet was washed twice with sterile $85 \%$ saline solution and recovered by centrifuging at $445 \times \mathrm{g}$ for 10 minutes.

\section{Effect of cell free supernatant of Lactobacillus species on fungal growth and aflatoxin production:}

The CFS of Lactobacillus species was inserted individually in 10-ml sterile Lablemco tryptone broth (LTB) for $L$. acidophilus and L. bulgaricus, while Tryptone soy broth (TSB) was used for $L$. casei, $L$. reuteri and $L$. gasseri in a dialysis sac with molecular weight 12,000 and 14,000 . Dialysis sacs were aseptically placed inside a $250-\mathrm{ml}$ flask containing $50-\mathrm{ml}$ sterile LTB for $L$. acidophilus and $L$. bulgaricus, while TSB was used for $L$. casei, $L$. reuteri and $L$. gasseri. Four treatments of this experiment were used as follows: CFS in dialysis sac was inoculated with $1 \mathrm{ml}\left(10^{6}\right)$ spore suspension 
AbdAlla, E. A. M. et al.

of $A$. parasiticus (T-1). The second treatment (T-2) CFS without dialysis sac was inoculated. The third treatment (T-3) CFS in dialysis sac and the fourth one (T-4) CFS without dialysis sac were maintained for 16 hours before spore suspension inoculation, then all treatments were incubated at $28^{\circ} \mathrm{C} \pm 2^{\circ} \mathrm{C}$ for 8 days. Aflatoxin production and mycelium dry weight were estimated.

Analysis: -

\section{1- Extraction of aflatoxins:}

The cultures were extracted twice with chloroform, and then they were filtered through glass wool. After which the filtrates were transferred to a separating funnel. The lower chloroform layer was passed through anhydrous sodium sulphate. The extracts were finely dried under nitrogen. The extracts were stored in vials at $-20^{\circ} \mathrm{C}$ until the aflatoxin determination

\section{2- Mycelium dry weight:}

The mycelium mats were collected by filtration through Whatman No. 4 filter paper, washed twice with water and dried in an oven at $95^{\circ} \mathrm{C}$ until constant weight and weighed.

\section{3- Determination of aflatoxins:}

Spots of extracted samples and aflatoxin standards were applied on a $(20 \times 20 \mathrm{~cm})$ pre- coated aluminum sheets of silica gel 60 without fluorescent indicator (TLC), activated at $105{ }^{\circ} \mathrm{C}$ for 2 hours. Extracted samples were dissolved in benzene: acetonitrile $(98: 2 \mathrm{v} / \mathrm{v})$. TLC plates were then developed in toluene: ethylacetate: $88 \%$ formic acid $(60: 30: 10 \mathrm{v} / \mathrm{v} / \mathrm{v})$. After development, TLC plates were dried and exposed to long wavelength ultraviolet light for visual estimation as describes by (Gourama and Bullerman, 1995).

\section{4- Apparatus:}

A DESAGA CD 60 spectrodensitometer was used in assay with a reflectance mode at excitation wave length $360 \mathrm{~nm}$, and emission wave length of $430 \mathrm{~nm}$. This was carried out by Micro Analytical center, Faculty of Science, Cairo University.

\section{5- Calculation of aflatoxins:}

Aflatoxin concentration was calculated as ppb by the following equation according to (AOAC Methods, 1990).

Where:

$$
\text { Aflatoxin (ppb) }=(B \times Y \times S \times V) /(Z \times X \times W)
$$

$B=$ area of aflatoxin peak in sample

$\mathrm{Y}=$ concentration of aflatoxin standard $\mu \mathrm{g} / \mathrm{ml}$

$\mathrm{S}=$ aflatoxin standard spotted $\mu \mathrm{l}$

$V=$ final dilution of sample extract $\mu \mathrm{l}$

$Z=$ area of aflatoxin peak in standard

$\mathrm{X}=$ sample extract spotted $\mu \mathrm{l}$

$\mathrm{W}=\mathrm{g}$ sample represented by final extract

Percentage of inhibition was calculated using the following equation:

$$
\{100 \text { - (treatment / control x 100)\} }
$$

\section{Effect of probiotic bacteria on total fungal count in Ras cheese}

Probiotic and traditional Ras cheese were manufactured at Dairy

Dept., Faculty of Agriculture, Ain Shams University according to the method 
described by Abu Sree (1997). Traditional Ras cheese (control) was processed using the normal starters $S$. thermophilus and L. bulgaricus (1: 1 $\mathrm{v} / \mathrm{v})$. For probiotic Ras cheese, two strains were used $L$. casei and $L$. reuteri $(1: 1 \mathrm{v} / \mathrm{v})$.

The un-waxed traditional Ras cheese (control) and the probiotic Ras cheese were sprayed with $A$. parasiticus spore suspension $\left(10^{6}\right)$. Cheese was ripened in a ripening cabinet $\left(90 \% \mathrm{RH}\right.$ and $\left.12 \pm 2^{\circ} \mathrm{C}\right)$ for 90 days.

Microbiological analysis:

Samples of probiotic and control of hard cheese were analyzed after 30 days, 60 days and 90 days of ripening period. Cheese samples were prepared according to the method recommended by APHA (1985), and examined for A. parasiticus count according to ICMSF (1996).

\section{Statistical analysis:}

It was carried out by the completely randomized design in factorial arrangement (F-test). The least significant variance (L. S. D) was used for comparing treatment means (Steel and Torrie, 1980).

\section{RESULTS AND DISCUSSION}

Fungal growth (as dry mycelium weight) and aflatoxins production (as ppb) by $A$. parasiticus were accounted for after 8 days of incubation for the control and the treatments (T-1, T-2, T-3 and T-4) of all probiotic strains.

1-Fungal growth:

Behavior of $A$. parasiticus growth in the presence of Lactobacillus species was studied. This behavior changed depending on Lactobacillus species used and the type of treatments. Data in Table (1) revealed that treatment T-2 of both $L$. acidophilus and $L$. bulgaricus was highly effective in inhibiting fungal growth followed by treatments $T-1, T-4$ and $T-3$ in descending order. In regard no real significant variance $(P>0.05)$ between control and all treatments was recorded for both $L$. acidophilus and $L$. bulgaricus

Results showed that all treatments of $L$. casei completely inhibited the fungal growth (100\%). On the other hand both L. gasseri and L. reuteri treatments T-3 and T-4 completely inhibited (100\%) fungal growth. Reduction $(61.54 \%)$ of the fungal growth was also recorded for T-2 of L. gasseri. Data revealed real significant variance $(P<0.05)$ between control and treatments $\mathrm{T}-2, \mathrm{~T}-3$ and $\mathrm{T}-4$ of $L$. gasseri and $L$. reuteri.

Data in Table (1) also showed that cell free supernatant of all tested strains incorporated in the flasks (T-2) was more active in inhibiting fungal growth than that incorporated in dialysis sac (T-1). On the other hand incorporation of bacteria used simultaneously with spore suspension of $A$. parasiticus was more effective in the inhibition of fungal growth than the incorporation of the bacteria 16 hours before spore suspension. The percentage of inhibition for $L$. acidophilus was $16.41 \%, 51.56 \%$ and $L$. bulgaricus $31.64 \%, 54.80 \%$ for treatments $\mathrm{T}-1$ and $\mathrm{T}-2$ respectively. In contrast $L$. gasseri and $L$. reuteri which were incorporated 16 hours before spore suspension (T-3 and T-4) completely inhibited (100\%) the fungal growth and was more effective than the incorporation simultaneously (T-1 and T-2). 
AbdAlla, E. A. M. et al.

Table (1): Effect of different Lactobacillus species on fungal growth and percentage of inhibition

\begin{tabular}{|c|c|c|c|c|c|c|c|c|c|c|}
\hline \multirow{3}{*}{ Treatments } & \multicolumn{10}{|c|}{ Lactobacillus species } \\
\hline & \multicolumn{2}{|c|}{ L. acidophilus } & \multicolumn{2}{|c|}{ L. bulgaricus } & \multicolumn{2}{|c|}{ L. casei } & \multicolumn{2}{|c|}{ L. gasseri } & \multicolumn{2}{|c|}{ L. reuteri } \\
\hline & A & B & A & B & $\mathbf{A}$ & B & $\mathbf{A}$ & B & $\mathbf{A}$ & B \\
\hline Control & \multicolumn{2}{|c|}{256} & \multicolumn{2}{|c|}{177} & \multicolumn{2}{|r|}{50} & \multicolumn{2}{|r|}{65} & \multicolumn{2}{|r|}{85} \\
\hline T-1 & 214 & $16.41 \%$ & 121 & $31.64 \%$ & $0^{*}$ & $100 \%$ & 55 & $15.38 \%$ & 43 & $49.41 \%$ \\
\hline T-2 & 124 & $51.56 \%$ & 80 & $54.80 \%$ & $0^{*}$ & $100 \%$ & $26^{*}$ & $61.54 \%$ & $0^{*}$ & $100 \%$ \\
\hline T-3 & 278 & & 153 & $13.56 \%$ & $0^{*}$ & $100 \%$ & $0^{*}$ & $100 \%$ & $0^{*}$ & $100 \%$ \\
\hline T-4 & 224 & $12.50 \%$ & 112 & $36.72 \%$ & 0 * & $100 \%$ & $0^{*}$ & $100 \%$ & $0^{*}$ & $100 \%$ \\
\hline L. S. D & & - & & - & & 0.74 & & 20.78 & & 24.38 \\
\hline
\end{tabular}

${ }^{*}$ Indicates a significant variance $(P<0.05)$

$A=m g$ fungal growth

$B=$ Percentage of inhibition

Fungal growth could be enhanced, retarded or remain unchanged as a result of another microorganism in the environment (El-Gendy and Marth, 1981), however the competitive growth is probably a factor in the inhibition of fungal growth (Bullerman et al., 1990). Inhibition of fungal growth may be due to the antifungal activity of the compounds produced by lactic acid bacteria (Plockova et al., 1997) such as organic acids (i.e. lactic and acetic acids) (De Muynck et al., 2004). Similar results were reported that culture supernatant of Lactobacillus species has reduced fungal growth of $A$. flavus. The inhibition of fungal growth was probably due to inactivating the viability of spores (Xu et al., 2003).

\section{2- Aflatoxin production:}

Recorded results in Table (2) showed that all treatments of $L$. acidophilus caused complete inhibition $(100 \%)$ of aflatoxin $\mathrm{G}_{2}$ showing real significant variance $(P<0.05)$, whereas treatment $T-1$ reduced aflatoxin $\mathrm{B}_{1}$ level by $23.74 \%$. On the other hand stimulation effect of aflatoxin $B_{1}$ production was recorded for the treatments T-2, T-3 and T-4. Regarding aflatoxin $\mathrm{B}_{2}$ treatments $\mathrm{T}-1$ and $\mathrm{T}-2$ caused the reduction of aflatoxin content by $45.76 \%$ and $19.04 \%$ respectively. In contrast treatments T-3 and T-4 caused the stimulation of aflatoxin production.

Table (2): Effect of $L$. acidophilus on aflatoxin production and percentage of inhibition

\begin{tabular}{|c|c|c|c|c|c|c|c|c|c|}
\hline \multirow{3}{*}{$\begin{array}{l}\text { Lactobacillus } \\
\text { species }\end{array}$} & \multirow{3}{*}{ Treatments } & \multicolumn{8}{|c|}{ Aflatoxins (ppb) } \\
\hline & & \multicolumn{2}{|c|}{$\mathrm{B}_{1}$} & \multicolumn{2}{|r|}{$\mathrm{B}_{2}$} & \multicolumn{2}{|c|}{$\mathrm{G}_{1}$} & \multicolumn{2}{|c|}{$\mathbf{G}_{2}$} \\
\hline & & $\mathbf{A}$ & B & $\mathbf{A}$ & B & $\mathbf{A}$ & B & $\mathbf{A}$ & B \\
\hline \multirow{6}{*}{$\begin{array}{l}\text { L. } \\
\text { acidophilus }\end{array}$} & Control & \multicolumn{2}{|c|}{1529} & \multicolumn{2}{|r|}{625} & \multicolumn{2}{|c|}{1773} & \multicolumn{2}{|c|}{310} \\
\hline & $\mathrm{T}-1$ & 1166 & $3.74 \%$ & 339 & $45.76 \%$ & $424^{*}$ & $76.09 \%$ & 0 * & $100 \%$ \\
\hline & T-2 & 2198 & + & 506 & $19.04 \%$ & 0 * & $100 \%$ & 0 * & $100 \%$ \\
\hline & T-3 & 5066 & + & 656 & + & $292^{*}$ & $83.53 \%$ & 0 * & $100 \%$ \\
\hline & $T-4$ & 6154 & + & 840 & + & $599^{*}$ & $66.22 \%$ & 0 * & $100 \%$ \\
\hline & L. S. D. & - & & - & & 0.141 & & .074 & \\
\hline
\end{tabular}

* Indicates a significant variance $(P<0.05)$

$A$ = Aflatoxin production (ppb)

$B=$ Percentage of inhibition

$+=$ Stimulation of aflatoxin production 
Data presented in Table (3) indicated that, $L$. bulgaricus treatments T-1, T-2, T-3 and T-4 caused complete inhibition (100\%) of aflatoxin $\mathrm{G}_{2}$ production, whereas all treatments reduced aflatoxins $B_{1}, B_{2}$ and $G_{1}$, where the percentage of inhibition ranged between $1.92 \%$ to $83.06 \%$ depending on the aflatoxin type and treatments.

Data also indicated that $L$. casei treatments completely prevented and inhibited the production of all aflatoxin types. Real significant variance $(P$ $<0.05)$ was recorded between control and all treatments for the two strains $L$. bulgaricus and L. casei.

Table (3): Effect of $L$. bulgaricus on aflatoxin production and percentage of inhibition

\begin{tabular}{|c|c|c|c|c|c|c|c|c|c|}
\hline \multirow{3}{*}{$\begin{array}{l}\text { Lactobacillus } \\
\text { species }\end{array}$} & \multirow{3}{*}{ Treatments } & \multicolumn{8}{|c|}{ Aflatoxins (ppb) } \\
\hline & & \multicolumn{2}{|r|}{$\mathbf{B}_{1}$} & \multicolumn{2}{|c|}{$\mathrm{B}_{2}$} & \multicolumn{2}{|c|}{$\mathrm{G}_{1}$} & \multicolumn{2}{|c|}{$\mathbf{G}_{2}$} \\
\hline & & $\mathbf{A}$ & B & $\mathbf{A}$ & B & A & B & $\mathbf{A}$ & B \\
\hline \multirow{6}{*}{ L. bulgaricus } & Control & \multicolumn{2}{|c|}{2001} & \multicolumn{2}{|c|}{625} & \multicolumn{2}{|c|}{1110} & \multicolumn{2}{|c|}{310} \\
\hline & T-1 & $836^{*}$ & $58.22 \%$ & 613 & $1.92 \%$ & $631 *$ & $43.15 \%$ & 0 * & $100 \%$ \\
\hline & T-2 & $395^{*}$ & $80.26 \%$ & $258^{*}$ & $58.72 \%$ & $525^{*}$ & $52.70 \%$ & 0 * & $100 \%$ \\
\hline & T-3 & $339^{*}$ & $83.06 \%$ & $227^{*}$ & $63.68 \%$ & $266^{*}$ & $76.04 \%$ & 0 * & $100 \%$ \\
\hline & T-4 & $685^{*}$ & $65.77 \%$ & $279^{*}$ & $55.36 \%$ & $212^{*}$ & $80.90 \%$ & 0 * & $100 \%$ \\
\hline & L. S. D. & \multicolumn{2}{|c|}{0.449} & \multicolumn{2}{|c|}{0.153} & \multicolumn{2}{|c|}{0.153} & \multicolumn{2}{|c|}{0.047} \\
\hline
\end{tabular}

* Indicates a significant variance $(P<0.05)$

$A=$ Aflatoxin production (ppb)

$B=$ Percentage of inhibition

Table (4) indicated that treatments T-3 and T-4 of the L. gasseri completely inhibited (100\%) the production of aflatoxin types. It was also noticed that treatment T-2 completely inhibited (100\%) aflatoxin $B_{2}$ and $G_{1}$ only showing real significant variance $(P<0.05)$. On the other hand treatment $T-1$ caused a slight stimulation of aflatoxin $B_{1}$ and $G_{1}$ production.

Table (4): Effect of L. gasseri on aflatoxin production and percentage of inhibition

\begin{tabular}{|c|c|c|c|c|c|c|c|c|c|}
\hline \multirow{3}{*}{$\begin{array}{l}\text { Lactobacillus } \\
\text { species }\end{array}$} & \multirow{3}{*}{ Treatments } & \multicolumn{8}{|c|}{ Aflatoxins (ppb) } \\
\hline & & \multicolumn{2}{|r|}{$B_{1}$} & \multicolumn{2}{|r|}{$\mathrm{B}_{2}$} & \multicolumn{2}{|c|}{$\mathbf{G}_{1}$} & \multicolumn{2}{|r|}{$\mathbf{G}_{2}$} \\
\hline & & $\mathbf{A}$ & B & $\mathbf{A}$ & B & A & B & $\mathbf{A}$ & B \\
\hline \multirow{6}{*}{ L. gasseri } & Control & \multicolumn{2}{|r|}{212} & \multicolumn{2}{|r|}{117} & \multicolumn{2}{|c|}{233} & \multicolumn{2}{|c|}{493} \\
\hline & $\mathrm{T}-1$ & 249 & + & 79 & $32.48 \%$ & 300 & + & 490 * & $0.61 \%$ \\
\hline & $\overline{T-2}$ & 236 & + & 0 * & $100 \%$ & 0 * & $100 \%$ & 84 * & $82.96 \%$ \\
\hline & $\mathrm{T}-3$ & 0 * & $100 \%$ & 0 * & $100 \%$ & 0 * & $100 \%$ & 0 * & $100 \%$ \\
\hline & $\bar{T}-4$ & $0 *$ & $100 \%$ & $0 *$ & $100 \%$ & 0 * & $100 \%$ & 0 * & $100 \%$ \\
\hline & L. S. D. & \multicolumn{2}{|c|}{0.222} & \multicolumn{2}{|c|}{1.120} & \multicolumn{2}{|c|}{0.090} & \multicolumn{2}{|c|}{0.095} \\
\hline
\end{tabular}

${ }^{*}$ Indicates a significant variance $(P<0.05)$

$A=$ Aflatoxin production (ppb)

$B=$ Percentage of inhibition

$+=$ Stimulation of aflatoxin production

Table (5) showed that treatments T-2, T-3 and T-4 L. reuteri caused complete inhibition (100\%) of all types of aflatoxins, whereas treatment T-1 only reduced aflatoxin $B_{2}, G_{1}$ and $G_{2}$ production and stimulated aflatoxin $B_{1}$ 
AbdAlla, E. A. M. et al.

production. In regard real significant variance $(P<0.05)$ was recorded between control and all treatments.

Table (5): Effect of $L$. reuteri on aflatoxin production and percentage of inhibition

\begin{tabular}{|c|c|c|c|c|c|c|c|c|c|}
\hline \multirow{3}{*}{$\begin{array}{l}\text { Lactobacillus } \\
\text { species }\end{array}$} & \multirow{3}{*}{ Treatments } & \multicolumn{8}{|c|}{ Aflatoxins (ppb) } \\
\hline & & \multicolumn{2}{|c|}{$B_{1}$} & \multicolumn{2}{|r|}{$\mathrm{B}_{2}$} & \multicolumn{2}{|c|}{$\mathbf{G}_{1}$} & \multicolumn{2}{|r|}{$\mathbf{G}_{2}$} \\
\hline & & A & B & A & B & A & B & A & B \\
\hline \multirow{6}{*}{ L. reuteri } & Control & \multicolumn{2}{|c|}{127} & \multicolumn{2}{|r|}{117} & \multicolumn{2}{|c|}{233} & \multicolumn{2}{|c|}{125} \\
\hline & T-1 & 246 & + & $42^{*}$ & $64.10 \%$ & $126^{\star}$ & $81.97 \%$ & 28 & $77.60 \%$ \\
\hline & $\mathrm{T}-2$ & 0 * & $100 \%$ & 0 * & $100 \%$ & $0^{*}$ & $100 \%$ & 0 * & $100 \%$ \\
\hline & $\mathrm{T}-3$ & 0 * & $100 \%$ & 0 * & $100 \%$ & 0 * & $100 \%$ & 0 * & $100 \%$ \\
\hline & $\mathrm{T}-4$ & 0 * & $100 \%$ & 0 * & $100 \%$ & 0 * & $100 \%$ & $0 *$ & $100 \%$ \\
\hline & L. S. D. & \multicolumn{2}{|c|}{0.099} & \multicolumn{2}{|c|}{0.033} & \multicolumn{2}{|c|}{0.060} & \multicolumn{2}{|c|}{0.020} \\
\hline
\end{tabular}

${ }^{*}$ Indicates a significant variance $(P<0.05)$

$A=$ Aflatoxin production (ppb)

$B=$ Percentage of inhibition

$+=$ Stimulation of aflatoxin production

Finally data in Table (6) revealed that cell free supernatants of $L$. casei, L. gasseri and L. reuteri incorporated in the flasks (T-2) were more effective in inhibiting aflatoxin production than those incorporated in dialysis sac (T-1). Whereas the incorporation of these bacteria 16 hours (T-3, T-4) before spore suspension of $A$. parasiticus completely inhibited aflatoxins and was more effective than the incorporation of bacteria simultaneously with spore suspension ( $\mathrm{T}-1, \mathrm{~T}-2)$.

In contrast cell free supernatant of $L$. acidophilus incorporated in dialysis sac ( $T-1)$ was more active in inhibiting aflatoxin production than that incorporated in the flask (T-2). Results also revealed that incorporation of this bacterium simultaneously with spore suspension was more effective in inhibiting aflatoxin production than incorporating the bacteria 16 hours before spore suspension.

Table (6): Effect of different Lactobacillus species on total aflatoxin production and percentage of inhibition

\begin{tabular}{|c|c|c|c|c|c|c|c|c|c|c|}
\hline \multirow{2}{*}{ Treatments } & \multicolumn{2}{|c|}{ L. acidophilus } & \multicolumn{2}{|c|}{ L. bulgaricus } & \multicolumn{2}{|c|}{ L. casei } & \multicolumn{2}{|c|}{ L. gasseri } & \multicolumn{2}{|c|}{ L. reuteri } \\
\hline & A & B & A & B & $A$ & B & A & B & A & B \\
\hline Control & \multicolumn{2}{|c|}{4237} & \multicolumn{2}{|c|}{4046} & \multicolumn{2}{|c|}{1330} & \multicolumn{2}{|c|}{1055} & \multicolumn{2}{|c|}{602} \\
\hline T-1 & 1929* & $54.47 \%$ & $2080^{*}$ & $48.59 \%$ & 0 * & $100 \%$ & 1118 & + & $442^{*}$ & $26.57 \%$ \\
\hline $\mathrm{T}-2$ & 2704 & $36.18 \%$ & $1178^{*}$ & $70.88 \%$ & 0 * & $100 \%$ & 320 * & $69.66 \%$ & $0^{*}$ & $100 \%$ \\
\hline-3 & 6014 & + & $832^{*}$ & $79.43 \%$ & 0 * & $100 \%$ & $0^{*}$ & $100 \%$ & 0 * & $100 \%$ \\
\hline-4 & 7593 & + & $1176^{*}$ & $70.93 \%$ & 0 * & $100 \%$ & $0^{*}$ & $100 \%$ & 0 * & $100 \%$ \\
\hline L. S. D. & \multicolumn{2}{|c|}{1.81} & \multicolumn{2}{|c|}{0.854} & \multicolumn{2}{|c|}{0.496} & \multicolumn{2}{|c|}{0.174} & \multicolumn{2}{|c|}{0.218} \\
\hline
\end{tabular}

* Indicates a significant variance $(P<0.05)$

$A=$ Aflatoxin production (ppb)

$B=$ Percentage of inhibition

$+=$ Stimulation of aflatoxins 
Aflatoxin production was affected by the presence of lactic acid bacteria. There is more than one mechanism involved in degradation of aflatoxins. The inhibition of aflatoxins was probably due to low molecular weight bacterial metabolites, which may have interfered with the synthesis of aflatoxins (Gourama and Bullerman, 1995). Other investigators proposed that adsorption of aflatoxins to bacterial cell wall may be the mechanism of aflatoxin degradation by lactic acid bacteria (Shah and $\mathrm{Wu}$, 1999). On the other hand the bacterial population and viability greatly affected the uptake of aflatoxins by cells (Line and Brackett, 1995).

\section{Effect of probiotic bacteria on total fungal count in Ras cheese}

Data in Table (7) revealed that fungal count in traditional Ras cheese was higher than that of probiotic Ras cheese. Data also showed that the number of fungal count highly varied. After 30 days of ripening total fungal count was $1.4 \times 10^{4}$ and $3 \times 10^{2}$ for traditional Ras cheese (control) and probiotic Ras cheese respectively. Fungal counts after 90 days of ripening were $1 \times 10^{5}$ and $4 \times 10$ for traditional Ras cheese (control) and probiotic Ras cheese respectively. From the previous results it could be demonstrated that probiotic bacteria incorporated in the Ras cheese had an effect and decreased the fungal growth in probiotic Ras cheese compared to the control. The possible explanation for the inhibition of growth and sporulation of moulds by lactic acid bacteria could be the facultative anaerobic conditions created by these bacteria in fermented food (Batish et al., 1997).

Both probiotic bacteria exerted antimycotic effect, this very beneficial safety property is very important since Ras cheese surface is usually contaminated with fungi and there is always a risk of aflatoxin production in the cheese. This also saved us the trouble of spraying the surface of cheese with antimycotic chemicals.

Table (7): Total fungal count (cfu/gm) of traditional and probiotic Ras cheese

\begin{tabular}{|l|c|c|c|}
\hline \multirow{2}{*}{ Type of cheese } & \multicolumn{3}{|c|}{ Ripening period (Days) } \\
\cline { 2 - 4 } \multicolumn{1}{|c|}{} & $\mathbf{3 0}$ & $\mathbf{6 0}$ & $\mathbf{9 0}$ \\
\hline Traditional Ras cheese (control) & $1.4 \times 10^{4}$ & $1.9 \times 10^{5}$ & $1 \times 10^{5}$ \\
\hline Probiotic Ras cheese & $3 \times 10^{2}$ & $4 \times 10$ & $4 \times 10$ \\
\hline
\end{tabular}

\section{Conclusion}

The probiotic strains $L$. casei, $L$. reuteri and $L$. gasseri were able to produce antifungal substances and were also able to inhibit aflatoxin production by $A$. parasiticus. From the effect exerted by these Lactobacillus species on fungal growth and aflatoxin production it would appear that they have the potential to be used as biological control agents in food to prevent fungal growth, where there is a strong indication that some inhibitory components are protein in nature. The antifungal and the antimycotoxigenic potential of Lactobacillus cultures have commercial applications and could be of great significance to both industry and consumers. Further investigations are needed to answer the behavior of these Lactobacillus strains and to purify and identify these compounds. 


\section{REFERENCES}

Abou-Donia, S. A. (2002): Recent development in Ras cheese research: A review. Egyptian Journal of Dairy Science, 30: 155 - 166.

Abu-Sree, Y. H. (1997): Effect of cheese processing and ripening of hard cheese on formation and stability of some mycotoxins. Ph. D. thesis, Faculty of Agriculture, Cairo University.

Association of Official Analytical Chemists (AOAC)(1990): Official methods of analysis, $15^{\text {th }}$ ed., AOAC, Washington, D. C.

American Public Health Association (APHA)(1985): Standard methods for the examination of dairy products. $15^{\text {th }}$ ed., Washington, D. C.,U. S. A.

Batish, V. K., Roy, U., Lal, R. and Grover, S. (1997): Antifungal attributes of lactic acid bacteria-A review. Critical Reviews in Microbiology, 17 (3): 209-225.

Brul, S., and Coote, P. (1999): Preservative agents in foods. Mode of action and microbial resistance mechanisms. International Journal of Food Microbiology, 50: 1-17.

Bullerman, L. B., Karunaratne, A. and Wezenberg, E., (1990): Inhibition of mould growth and aflatoxin production by Lactobacillus species. Journal of Food Protection, 53 (3): 230-236.

Carr, F. J., Chill, D.and Maida, N. (2002): The lactic acid bacteria: a literature survey. Critical Reviews in Microbiology, 28, 281-370.

Dabiza, N. A. and Fathi, F. A. (2003): The antibacterial effect of probiotic bacteria isolated from some dairy products. Egyptian Journal of Dairy Science, 33: 49-64.

Davidson, M. P. (2001): Chemical preservatives and natural antimicrobial compounds. In M. P. Doyle, L. R. Beuchat, \& T. J. Montville (Eds.), Food microbiology: Fundamentals and frontiers (pp. 593-627). Washington: ASM press.

De Muynck, C., Leroy, A. I. J., De Maeseneire, S., Arnaut, F., Soetaert, W. and Vandamme, E. J. (2004): Potential of selected lactic acid bacteria to produce food compatible antifungal metabolites. Microbiological Research, 159: 339-346.

Eaton, D. L.and Gallagher, E. P., (1994): Mechanisms of aflatoxin carcinogenesis. Annual Review of Pharmacological Toxicology, 34: 135-172.

El Gendy, S. M. and Marth, E. H. (1981): Growth and aflatoxin production by Aspergillus parasiticus in the presence of Lactobacillus casei. Journal of Food Protection, 44 (3): 211-212.

Ellis, W. O., Smith, J. P. and Simpson, B. K., (1991): Aflatoxins in food: occurrence, biosynthesis, effects on organisms, detection, and methods of control. Critical Review in Food Science and Nutrition, 30: 403-439.

El-Nezami, H., Mykkanen, H., Kankaanpaa, P., Salminen, S. and Ahokas, J., (2000): Ability of Lactobacillus and Propionibacterium strains to remove aflatoxin $B_{1}$ from the chicken duodenum. Journal of Food Protection, 63: 549-552. 
Farkas, J. (2001): Physical methods for food preservation. In M. P. Doyle, L. R. Beuchat, \& T. J. Montville (Eds.), Food microbiology: Fundamentals and frontiers (pp. 567-592). Washington: ASM Press.

Gourama, H. and Bullerman, L. B., (1995): Antimycotic and anti-aflatoxigenic effect of lactic acid bacteria. A review. Journal of Food Protection, 57: 1275-1280.

International Agency for Research on Cancer (IARC) (1993): Some Naturally Occurring Substances: Food Items and Constituents, Heterocyclic Aromatic Amines and Mycotoxins. IARC Monographs on the Evaluation of Carcinogenic Risks to Humans. Volume 56. IARC, Lyon, France.

International Committee on Microbiological Specifications for Foods (ICMSF) (1996): Microorganisms in foods, their significance and methods of enumeration. $2^{\text {nd }} \mathrm{Ed}$., University of Toronto Press, Toronto and Buffals, Canada.

Line, J. E. and Brackett, R. E. (1995): Factors affecting aflatoxin $B_{1}$ removal by Flavobacterium aurantiacum. Journal of Food Protection, 58: 9194.

Montagna, M. T., Santacroce, M. P., Spilotros, G., Napoli, C., Minervini, F., Papa, A. and Dragoni, I. (2004): Investigation of fungal contamination in sheep and goat cheeses in southern Italy. Mycopathologia. 158(2): 245-249.

Oruc, H. H. and Sonal, S. (2001): Determination of aflatoxin $M_{1}$ levels in cheese and milk consumed in Bursa, Turkey. Vet Hum Toxicol., 43(5): 292-293.

Park, D. C. (1993): Controlling aflatoxin in food and feed. Food Technology, October, 92-96.

Pelonen, K., El-Nezami, H., Haskard, C., Ahokas, J. and Salminen, S. (2001): Aflatoxin B1 binding by dairy strains of lactic acid bacteria and Bifidobacteria. Journal of Dairy Science, 84: 2152-2156.

Phillips, T. D., Clement, B. V. and Park, D. L. (1994): Approaches to reduction of aflatoxins in foods and feeds. In the Toxicology of aflatoxins: Human health, Veterinary and agriculture significance. Edited by Eaton, D. L. and Groopman, J. D. pp383-406. Academic press, London.

Piva, G., Galvano, F., Pietri, A. and Piva, A. (1995): Detoxification methods of aflatoxins. A review. Nutrition Research, 15: 689-715.

Plockova, M., Chumchalova, J. and Tomanova, J. (1997): Antifungal activity of Lactobacillus acidophilus CH5 metabolites. Potrav. Vedy., 15 (1): 39-48.

Ross, P. R., Morgan, S. and Hill, C. (2002): Preservation and fermentation: past, present and future. International Journal of Food Microbiology, 79: 3-16.

Schnurer, J. and Magnusson, J. (2005): Antifungal lactic acid bacteria as biopreservatives. Review. Trends in Food Science and Technology, 16: 70-78.

Shah, N. and Wu, X. (1999): Aflatoxin $\mathrm{B}_{1}$ binding abilities of probiotic bacteria. Bioscience and Microflora, 18: 43-48 
AbdAlla, E. A. M. et al.

Shetty, P. H. and Jespersen, L. (2006): Saccharomyces cerevisiae and lactic acid bacteria as potential mycotoxin decontamination agent. Trends in Food Science and Technology, 17: 48-55.

Sreekuman, O. and Hosono, A., (1998): Antimutagenicity and the influence of physical factors in binding Lactobacillus gasseri and Bifidobacterium longum cells to amino acid pyrolysates. Journal of Dairy Science, 81:1506-1516.

Steel, R. G. G. and Torrie, J. H. (1980): Introduction to statistics, International student edition. Mc Grow Hill - Kogak, U. S. A.

Van Egmond, H. P. (1989): Current situation on regulations for mycotoxins. Overview of tolerances and status of standard methods of sampling and analysis, Food Additives Contaminant, 6: 139-188.

Wood, G. E., (1989): Aflatoxin in domestic and imported foods and feeds. Journal of AOAC, 72: 543-548.

Xu, J., Wang, H., Ji, R. and Luo, X. (2003): Study on the effect of the growth and aflatoxin production by Aspergillus flavus parasiticus NNRL 2999 in the present of Lactobacillus plantarum ATCC 8014. Wei Sheng Yan Jiu., 32 (4): 334-338.

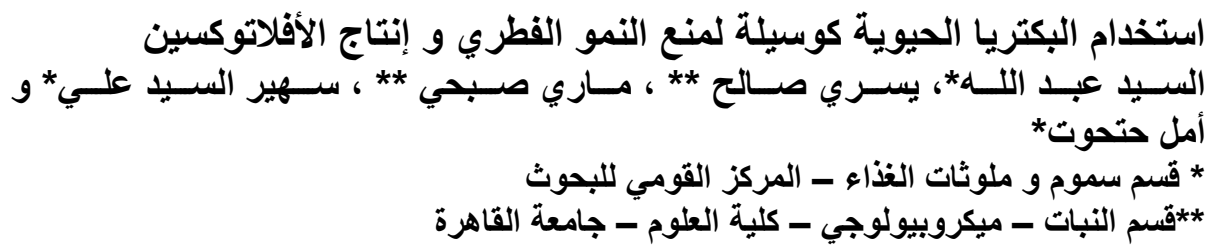

تستخدم سلالات الـ Lactobacillus كبكتريا حيوية في منتجات الألبان المتخمرة و كذللك في

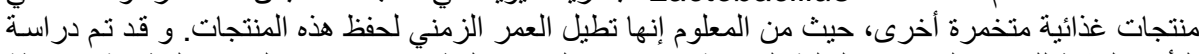

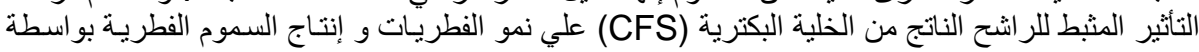
A. parasiticus

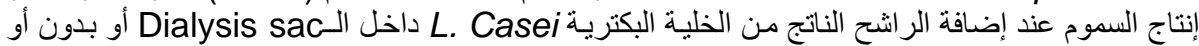

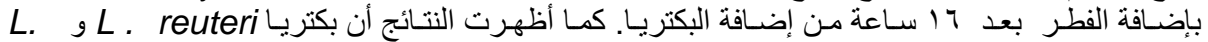
gasseri

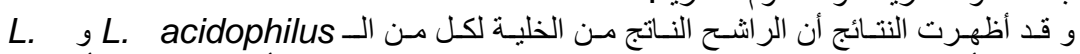
bulgaricus

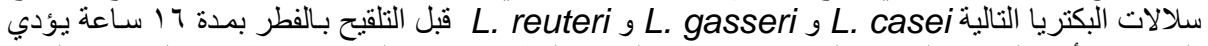

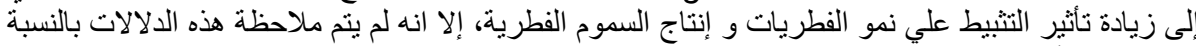

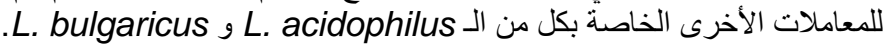

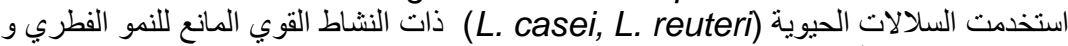

أدخلت قي صناعة الجبن الرأس لتحل محل البادئات الطبيعية (S. thermophilus, L. bulgaricus) حيث منعت نمو الفطر خلال فترة التخزين.

و في النهاية يمكن استتناج أن البكتريا الحيوية تستطيع إنتاج مو اد فعالة يمكنها تثبيط إنتاج السموم

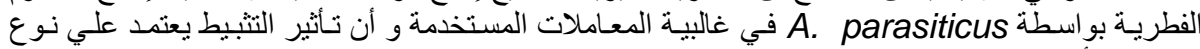
البكتريا و/أو المعاملات المستخدمة. 